\title{
Thermodynamic and kinetic studies of biosorption of iron and manganese from aqueous medium using rice husk ash
}

\author{
F. A. Adekola $\cdot$ D. S. S. Hodonou $\cdot$ H. I. Adegoke
}

Received: 10 December 2013/ Accepted: 21 July 2014/Published online: 26 November 2014

(C) The Author(s) 2014. This article is published with open access at Springerlink.com

\begin{abstract}
The adsorption behavior of rice husk ash with respect to manganese and iron has been studied by batch methods to consider its application for water and waste water treatment. The optimum conditions of adsorption were determined by investigating the effect of initial metal ion concentration, contact time, adsorbent dose, $\mathrm{pH}$ value of aqueous solution and temperature. Adsorption equilibrium time was observed at $120 \mathrm{~min}$. The adsorption efficiencies were found to be $\mathrm{pH}$ dependent. The equilibrium adsorption experimental data were found to fit the Langmuir, Freundlich and Temkin isotherms for iron, but fitted only Langmuir isotherm for manganese. The pseudosecond order kinetic model was found to describe the manganese and iron kinetics more effectively. The thermodynamic experiment revealed that the adsorption processes involving both metals were exothermic. The adsorbent was finally applied to typical raw water with initial manganese and iron concentrations of $3.38 \mathrm{mg} / \mathrm{l}$ for $\mathrm{Fe}$ and $6.28 \mathrm{mg} / \mathrm{l}$, respectively, and the removal efficiency was $100 \%$ for $\mathrm{Mn}$ and $70 \%$ for Fe. The metal ions were desorbed from the adsorbent using $0.01 \mathrm{M} \mathrm{HCl}$, it was found to quantitatively remove 67 and $86 \%$ of $\mathrm{Mn}$ and $\mathrm{Fe}$, respectively, within $2 \mathrm{~h}$. The results revealed that manganese and iron are considerably adsorbed on the adsorbent and could be an economic method for the removal of these metals from aqueous solutions.
\end{abstract}

Keywords Thermodynamics - Kinetics - Biosorption . Rice husk ash · Isotherms

F. A. Adekola · D. S. S. Hodonou · H. I. Adegoke $(\square)$ Department of Chemistry, University of Ilorin, Ilorin, Nigeria e-mail: adegoke.hi@unilorin.edu.ng

F. A. Adekola

e-mail: fadekola@unilorin.edu.ng

\section{Introduction}

Water pollution is a major global problem which requires ongoing evaluation and revision of water resource policy at all levels (international down to individual aquifers and wells). It has been suggested that it is the leading worldwide cause of deaths and diseases, and that it accounts for the deaths of more than 14,000 people daily. The contamination of both surface and groundwater by heavy metals constitutes an environmental hazard due to the fact that metals are not biodegradable and can cause severe adverse effects on human health (Spellman 2001).

The presence of iron and manganese compounds, in groundwater, and eventually in drinking water, is a serious environmental problem which poses a substantial risk to local resource user and to the natural environment. Many techniques have been developed for removing heavy metals from water and wastewater and these include polyphosphate treatment, ion-exchange treatment, precipitations, ultra filtration and chlorination (Bruce Seelig 1998). Recently the uses of some natural biomaterials as adsorbents have been advocated. The advantages of biosorbents include low operational cost and biodegradability. Biomaterials that have been used to remove heavy metals from aqueous solution include rice husk carbon, phosphatetreated rice husk, and rice husk carbon, Moringa seeds (Jahn 1988). Sari et al. in their study reported the biosorption characteristics of $\mathrm{Cd}$ (II) and $\mathrm{Cr}(\mathrm{III})$ ions from aqueous solution using moss (Hylocomium splendens) biomass. In their report, experimental data fitted into Langmuir model better than Freundlich isotherm. The calculated thermodynamic parameters showed that the biosorption of the metal ions studied onto the biomass was feasible, spontaneous and exothermic under examined conditions (Sari et al. 2008). In another related study, 
biosorption characteristics of $\mathrm{Pb}(\mathrm{II})$ and $\mathrm{Cd}$ (II) ions from aqueous solution using microfungus (Amanita rubescens) biomass were investigated as a function of $\mathrm{pH}$, contact time, temperature and some other parameters. The biosorption of the metal ions by Amanita rubescens fitted into Langmuir model better than Freundlich isotherm (Sari and Tuzen 2009).

The main objective of this study is to investigate the potential use of rice husk ash, an agricultural waste material as low cost bio-adsorbent for removal of iron and manganese ions from aqueous solution and real raw water from a local dam. The effect of some physical-chemical and thermodynamic parameters such as $\mathrm{pH}$, adsorbent dose, temperature, ionic strength, the effect of initial concentration, the effect of contact time on the sorption capacity were investigated.

\section{Materials and methods}

Collection of rice husk waste material

Rice-husk, an agro-residue waste material was collected from a processing center at a local market in Ilorin, Kwara State of Nigeria.

\section{Preparation of adsorbents}

The rice husk (RH) was milled and later washed with distilled water to remove all impurities. The material was then oven dried at $105{ }^{\circ} \mathrm{C}$ for $5-6 \mathrm{~h}$. It was thereafter sieved and the fraction with particle size $300<\phi<250 \mu \mathrm{m}$ was selected for further pretreatment. The RH was purified in $500 \mathrm{ml}$ of $0.3 \mathrm{M}$ of $\mathrm{HNO}_{3}$ (Merck South Africa) over night and mechanically stirred at moderate speed; it was then washed thoroughly with large quantity of distilled water to neutrality and subsequently air dried at $105{ }^{\circ} \mathrm{C}$ for $24 \mathrm{~h}$ (Laurence and Christopher 1989; Abdullah et al. 2001). The material was ashed at $550{ }^{\circ} \mathrm{C}$ in the muffle furnace and labeled, Ash-RH.

\section{Characterization of adsorbents}

The specific surface area was determined using Sears' method (Shawabkeh et al. 2003).

The elemental composition of the adsorbent was determined using X-ray fluorescence (XRF) spectrometry.

The major functional groups in the adsorbent were determined by Fourier transform infrared spectrometry (FTIR-8400S). It was used to determine the functional groups in the samples at wave number $400-4,000 \mathrm{~cm}^{-1}$.
The $\mathrm{pH}$ of the adsorbent was determined by weighing $1 \mathrm{~g}$ of Ash-RH, boiled in a beaker containing $100 \mathrm{ml}$ of distilled water for $5 \mathrm{~min}$. The solution was diluted to $200 \mathrm{ml}$ with distilled water and cooled at room temperature, the $\mathrm{pH}$ of each was measured using a $\mathrm{pH}$ meter (model ATPH-6) and the readings were recorded (Abdullah et al. 2001).

The bulk density of Ash-RH was determined using Archimedes's principle. The bulk density was determined using the equation below (Toshiguki and Yukata 2003).

Bulk density $=\frac{W_{2}-W_{1}}{V}$

where $W_{1}$, is the weight of empty measuring cylinder, $W_{2}$ is the weight of cylinder filled with sample and $V$ is the volume of cylinder.

The turbidity of the adsorbent particles suspension in aqueous media was used to evaluate the rate of agglomeration and sedimentation of rice husks ash (Ash-RH) particles. The turbidity study of the adsorbent was carried out to determine the influence of $\mathrm{pH}$ on the sedimentation behavior of the adsorbent particles. The study was carried out by varying the $\mathrm{pH}$ of colloidal suspension of $0.1 \mathrm{~g}$ biosorbent in $20 \mathrm{ml}$ of aqueous solution between 3 and 7 . The turbidity value was measured at various time intervals using a HACH turbidimeter model 2,100 N.

Batch adsorption experiments

The adsorption experiments were conducted using $0.1 \mathrm{~g}$ of Ash-RH with $20 \mathrm{ml}$ of solutions containing heavy metal ions of desired concentrations at constant temperature of $30 \pm 2{ }^{\circ} \mathrm{C}$ in $100 \mathrm{ml}$ plastic bottles. The mixtures were shaken on a shaker for $5 \mathrm{~h}$ and mixtures were filtered through Whatman filter paper No 1. The exact concentrations of metal ions in the initial and final solution were determined spectrophotometrically. The percent (\%) adsorbed was calculated using the equation below (Uberoi et al. 1990).

$\%$ Adsorption $=\frac{C_{0}-C_{e}}{C_{0}} \times 100$

where $C_{0}$ and $C_{e}$ are the initial and final concentrations of the metal ions in solution, respectively.

Adsorption isotherms studies

The experimental data were fitted using Langmuir (Hall et al. 1966) Freundlich (Hutson and Yang 1997) and Temkin adsorption isotherms.

The Langmuir isotherm equation is written as:

$\frac{C_{\mathrm{e}}}{q_{\mathrm{e}}}=\frac{1}{q_{\max } K_{L}}+\frac{C_{\mathrm{e}}}{q_{\max }}$ 
where $C_{\mathrm{e}}$ is the equilibrium concentration of adsorbate $\left(\mathrm{mg} / \mathrm{l}^{-1}\right)$ and $q_{\mathrm{e}}$ is the amount of metal adsorbed per gram of the adsorbent at equilibrium $(\mathrm{mg} / \mathrm{g}) \cdot q_{\mathrm{m}}(\mathrm{mg} / \mathrm{g})$ and $b(\mathrm{l} /$ $\mathrm{mg}$ ) are Langmuir constants related to adsorption capacity and rate of adsorption, respectively. The values of $q_{\mathrm{m}}$ and $b$ were calculated from the slope and intercept of the Langmuir plot of $C_{\mathrm{e}}$ versus $C_{\mathrm{e}} / q_{\mathrm{e}}$ (Langmuir 1918).

Freundlich isotherm describes an empirical relationship that exists between the adsorption of solute and the surface of the adsorbent. This isotherm could be effectively utilized to study the heterogeneity and surface energies. The empirical equation proposed by Freundlich is:

$q=K_{\mathrm{f}} C^{1 / n}$

where, $K_{\mathrm{f}}$ and $n$ are coefficients; $q$ is the weight adsorbed per unit weight of adsorbent; $C$ is the concentration of the metal solution

Taking logarithm and rearranging: $\log q$

$$
=\log K_{\mathrm{f}}+\frac{1}{n} \log C
$$

The constant $K_{\mathrm{f}}$ is an approximate indicator of adsorption capacity, while $1 / n$ is a function of the strength of adsorption in the adsorption process. These constants can be evolved by linearising the above equation by adopting mathematical techniques (Voudrias et al. 2002).

If $\mathrm{n}$ is equal to 1 then the partition between the two phases is independent of the concentration. If the $1 / n$ value is below 1 it indicates a normal adsorption. On the other hand if $1 / n$ is above 1 it indicates cooperative adsorption (Mohan and Karthikeyan 1997).

\section{Temkin adsorption isotherm}

The Temkin isotherm model assumes that the adsorption energy decreases linearly with the surface coverage due to adsorbent-adsorbate interactions. The Temkin isotherm equation is applied for isotherm analysis in the following form (Temkin and Pyzhev 1940):

$q_{\mathrm{e}}=B \ln A+B \ln C_{\mathrm{e}}$

where $C_{\mathrm{e}}$ is the equilibrium concentration of adsorbate $\left(\mathrm{mg} / \mathrm{l}^{-1}\right)$ and $q_{\mathrm{e}}$ is the amount of metal adsorbed per gram of the adsorbent at equilibrium $(\mathrm{mg} / \mathrm{g})$.

According to Temkin isotherm, the linear form can be expressed by equation

$q_{\mathrm{e}}=\frac{R T}{b} \ln K_{\mathrm{T}}+\frac{R T}{b} \ln C_{\mathrm{e}}$

where $R T / b=B(\mathrm{~J} / \mathrm{mol})$, which is the Temkin constant related to heat of sorption, whereas $K_{\mathrm{T}}(1 / \mathrm{g})$ represents the equilibrium binding energy, $R(8.314 \mathrm{~J} / \mathrm{mol} / \mathrm{K})$ is the universal gas constant at $T(\mathrm{~K})$ which is the absolute solution temperature.

Adsorption kinetics studies

The pseudo-first order and pseudo-second order models have been tested on the experimental data at different contact time. The pseudo-first order model is expressed using this equation (Ho et al. 1996)

$\log \left(q_{\mathrm{e}}-q\right)=\log q_{\mathrm{e}}-\frac{K_{\mathrm{ad}}}{2.303} \times t$

where $q_{\mathrm{e}}(\mathrm{mg} / \mathrm{g})$ is the mass of metal adsorbed at any time $t$ and $k_{1}\left(\mathrm{~min}^{-1}\right)$ is the equilibrium rate constant of pseudofirst order adsorption. The values of $k_{\mathrm{ad}}$ and $q_{\mathrm{e}}$ are determined from the slope and intercept of the plot of $\log \left(q_{\mathrm{e}}-\right.$ $q_{\mathrm{t}}$ ) versus $\mathrm{t}$, respectively.

The pseudo-second order model is based on assumption that biosorption follows a second order mechanism. The rate of occupation of adsorption sites is proportional to the square of the number of unoccupied sites (Mckay and Ho 1999). The equation can be expressed as Ho and McKay (2002):

$\frac{t}{q_{\mathrm{t}}}=\frac{1}{k_{2} q_{\mathrm{e}}^{2}}+\frac{1}{q_{\mathrm{e}}} \times t$

where $k_{2}$ is the pseudo-second order rate constant $(\mathrm{g} / \mathrm{mg} /$ $\min )$. The value of $q_{\mathrm{e}}$ is determined from the slope of the plot of $t / q_{\mathrm{t}}$ versus $t$.

\section{Thermodynamic study}

The thermodynamic parameters were obtained by varying the temperature conditions between 30 and $50{ }^{\circ} \mathrm{C}$ while keeping other variables constant including metal concentration, $\mathrm{pH}$, adsorbent dose, contact time. The values of the thermodynamic parameters such as $\Delta G^{\mathrm{o}}, \Delta H^{\mathrm{o}}$, and $\Delta S^{\mathrm{o}}$, were calculated using the expression described below (Khan et al. 2005):

The Gibb's free energy of the adsorption process is calculated (Voudrias et al. 2002)

$\Delta G=-R T \ln K_{\mathrm{d}}$

where $\Delta G^{\mathrm{o}}$ is the standard Gibb's free energy change for the adsorption $(\mathrm{J} / \mathrm{mol}), R$ is the universal gas constant $(8.314 \mathrm{~J} / \mathrm{mol} / \mathrm{K})$ while $T$ is the temperature $(\mathrm{K}) . K_{\mathrm{d}}$ is the distribution coefficient of the adsorbate The plot of $\ln K_{\mathrm{d}}$ versus $1 / T$ gives a straight line with the slope and the intercept giving values of $\Delta H^{\mathrm{o}}$ and $\Delta S^{\mathrm{o}}$.

$\operatorname{In} K_{\mathrm{d}}=\Delta S / R-\Delta H / R T$

These values could be used to compute $\Delta G^{\mathrm{o}}$ from the Gibb's relation, 
$\Delta G=\Delta H-T \Delta S$

where $K_{\mathrm{d}}$ is the distribution coefficient of the adsorbate, and it is equal to $q_{\mathrm{e}} / C_{\mathrm{e}}(1 / \mathrm{g}) . T$ is the temperature $(\mathrm{K})$, $R=8.314 \times 10^{-3} \mathrm{~kJ} \mathrm{~K}^{-1} \mathrm{~mol}^{-1}, q_{\mathrm{e}}$ is quantity of metal ion sorbed $(\mathrm{mg} / \mathrm{g})$ and $C_{\mathrm{e}}$ is the equilibrium concentration of metal ion solution $(\mathrm{mg} / \mathrm{l}) . \Delta G$ was calculated from the equation at temperature of 303-323 K.

Synergetic effect of metals in binary solution

Understanding of the synergetic effect is important for evaluating the degree of interference posed by associated metal ions in adsorptive treatment of waste water. Binary adsorption of metal ions was conducted with the same operating conditions as for mono-component adsorption in terms of volume $(20 \mathrm{ml})$, adsorbent dose $0.1 \mathrm{~g}$, and agitation time of $2 \mathrm{~h}$. The simultaneous adsorption of $\mathrm{Mn}$ (II) and $\mathrm{Fe}(\mathrm{II})$ ions from binary mixtures was also investigated at $\mathrm{pH} 5$ and temperature of $30 \pm 2{ }^{\circ} \mathrm{C}$. The quantities adsorbed were determined by subtracting the quantity of the heavy metals in each filtrate from the initial quantity of heavy metal in each binary solution before contact.

\section{Desorption experiment}

The regeneration of the adsorbent was undertaken by carrying out batch desorption experiments.

Different concentrations of $\mathrm{HCl}(0.05,0.1,0.2 \mathrm{M})$ were contacted with the $\mathrm{Mn}$ (II) or $\mathrm{Fe}(\mathrm{II})$ presorbed adsorbent in different conical flasks and each suspension was equilibrated at different time intervals $(10,20,30,60$ and $120 \mathrm{~min}$ ). After equilibration, the mixtures were filtered and filtrates were analyzed for the amount of $\mathrm{Mn}$ (II) and $\mathrm{Fe}(\mathrm{II})$ in the solution. A graph of the percentage desorbed was plotted against time.

Desorption index

The desorption index was used to determine the degree of the reversibility of the sorption process. It is the ratio of the percent of total metal adsorbed after sorption to the percentage total left on the adsorbent after desorption.

\section{Application of batch optimization conditions for the removal of $\mathrm{Mn}$ and $\mathrm{Fe}$ from untreated dam water}

Untreated raw water was collected from Unilorin campus dam on 9 May 2012 and was appropriately preserved by acidifying with few drop of $0.5 \mathrm{M}$ of $\mathrm{HCl}$ to prevent precipitation of the metal ions. The batch optimization
Table 1 Physico-chemical properties of rice husk ash

\begin{tabular}{ll}
\hline Properties & Ash-RH \\
\hline $\mathrm{pH}$ & 7.1 \\
Bulk density $(\mathrm{g} / \mathrm{ml})$ & 0.3277 \\
Particle size & $300<\phi<250 \mu \mathrm{m}$ \\
Surface area $\left(\mathrm{m}^{2} / \mathrm{g}\right)$ & 54.1 \\
\hline
\end{tabular}

Table 2 Elemental composition of rice husk ash

\begin{tabular}{lc}
\hline Elements & Ash-RH \\
\hline $\mathrm{K}(\mathrm{w} \%)$ & $1.82 \pm 0.0213$ \\
$\mathrm{Ca}(\mathrm{ppm})$ & $903 \pm 436$ \\
$\mathrm{Mn}(\mathrm{ppm})$ & $23 \pm 2$ \\
$\mathrm{Fe}(\mathrm{ppm})$ & $126 \pm 3$ \\
$\mathrm{Cu}(\mathrm{ppm})$ & $3 \pm 0$ \\
$\mathrm{Zn}(\mathrm{ppm})$ & $13 \pm 4$ \\
$\mathrm{Ni}(\mathrm{ppm})$ & $5 \pm 1$ \\
\hline
\end{tabular}

conditions were applied for the removal of $\mathrm{Mn}$ and $\mathrm{Fe}$ in Unilorin dam water, after contact with the adsorbent Ash-RH.

\section{Results and discussion}

The physical properties of the Ash-RH are summarized in the Table 1.

XRF elemental analysis

The elemental composition of Ash-RH biomass using XRF technique is summarized in Table 2. It shows that $\mathrm{Ca}$ and $\mathrm{K}$ are present as major elements; $\mathrm{Fe}$ exists as minor while $\mathrm{Mn}, \mathrm{Zn}, \mathrm{Cu}$ and $\mathrm{Ni}$ exist at trace levels.

\section{Results of adsorption studies}

Effect of initial concentration on adsorption of Fe(II) and $\mathrm{Mn}(\mathrm{II})$ ions

The results obtained are presented in Fig. 1. Two different behaviors were observed for iron and manganese, while the former exhibited a higher increase in the quantity of metal adsorbed with initial concentration, the latter showed a slight increase. The quantity adsorbed for $\mathrm{Mn}$ and $\mathrm{Fe}$ at $100 \mathrm{ppm}$ was 3.21 and $18.84 \mathrm{mg} / \mathrm{g}$, respectively. It is, therefore, evident that rice husk ash has higher capacity for iron than manganese. This may also be attributed to an increase in the driving force of the concentration gradient with the increase in the initial metal concentration (Kalavathy and Miranda 2010). 


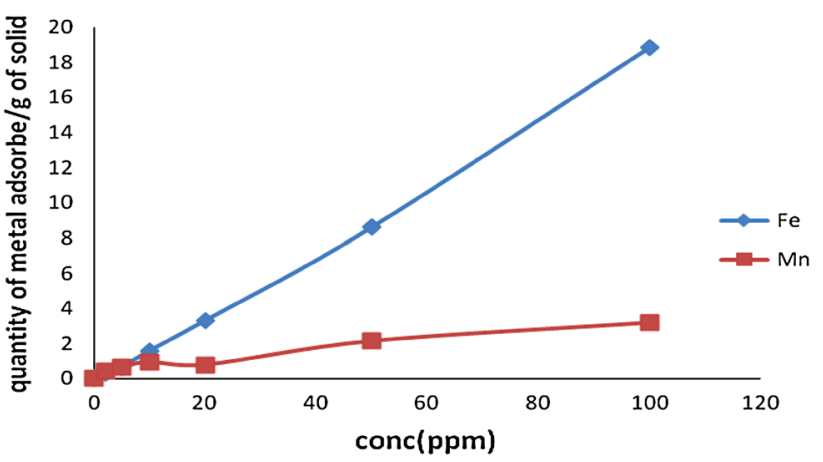

Fig. 1 Variation of initial metal ions concentration on the sorption capacity of iron and manganese: $m=0.1 \mathrm{~g}, V=20 \mathrm{ml}$, time $7 \mathrm{~h}$, temperature $30{ }^{\circ} \mathrm{C}$

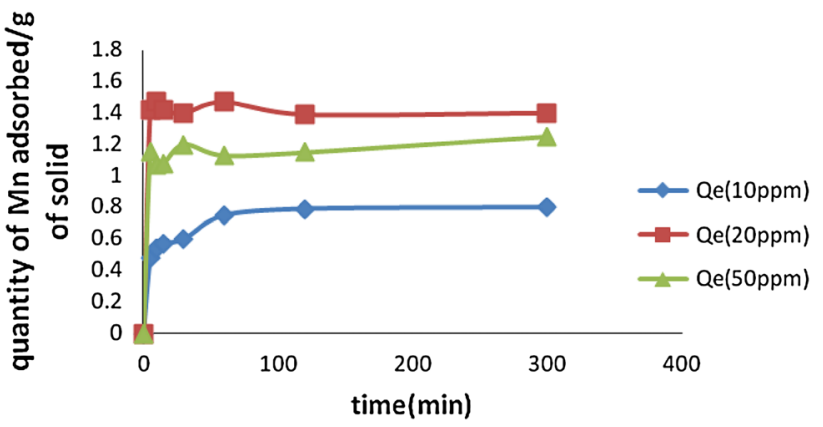

Fig. 2 Effect of contact time on the sorption of $\mathrm{Mn}$ (II) by Ash-RH $\left(m=0.1 \mathrm{~g}, V=20 \mathrm{ml}, \mathrm{pH} 5\right.$, temperature of $30^{\circ} \mathrm{C}$, concentration $10-50 \mathrm{ppm})$

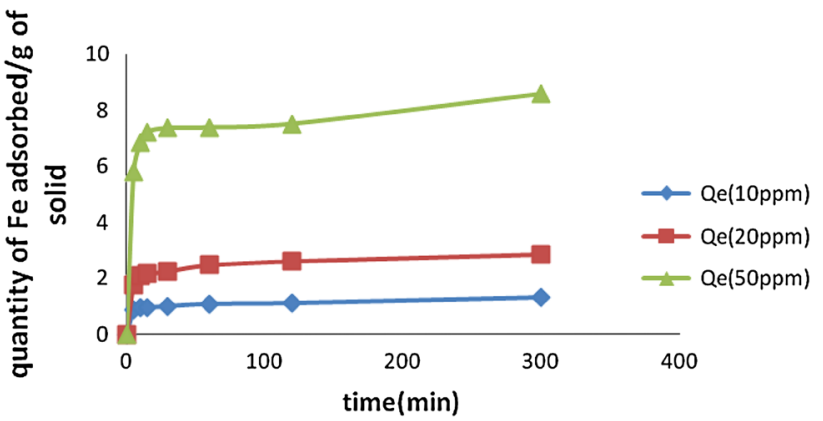

Fig. 3 Effect of contact time on the sorption of Fe(II) by Ash-RH $\left(m=0.1 \mathrm{~g}, V=20 \mathrm{ml}, \mathrm{pH} 5\right.$, temperature of $30^{\circ} \mathrm{C}$, concentration $10-50 \mathrm{ppm})$

\section{Effect of contact time}

The effect of contact time on adsorption is of importance in adsorption process, because of its influence on the adsorption capacity (Baysal 2009). The uptake of Mn(II) and $\mathrm{Fe}(\mathrm{II})$ ions were studied over a time range 5-300 min. The effect of contact time on removal efficiency is presented in Figs. 2 and 3. The results show that there is initial rapid increase in the quantity adsorbed within the first $10 \mathrm{~min}$ before approaching a plateau at about $100 \mathrm{~min}$ for

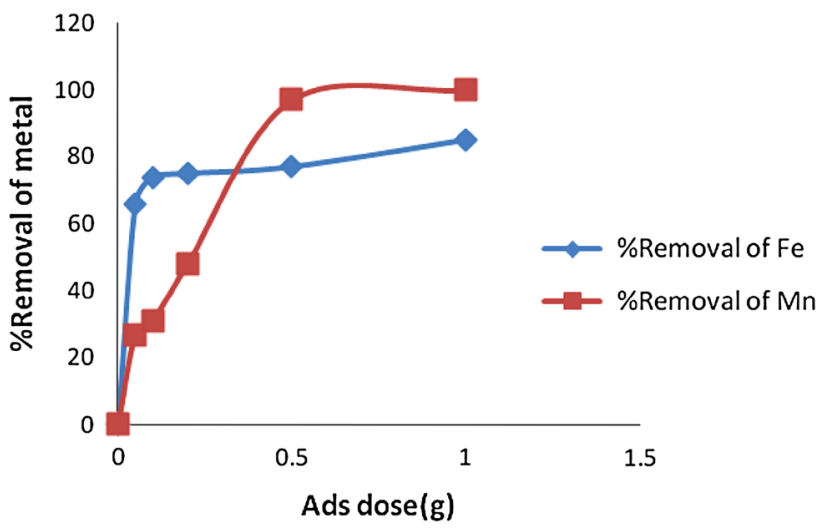

Fig. 4 Effect of adsorbent dose on \% removal on the sorption of $\mathrm{Mn}(\mathrm{II})$ and $\mathrm{Fe}(\mathrm{II})$ on Ash-RH $(m=0.1 \mathrm{~g}, \quad V=20 \mathrm{ml}, \mathrm{pH} 5$, temperature of $30{ }^{\circ} \mathrm{C}$, concentration $10 \mathrm{ppm}$, time $120 \mathrm{~min}$ )

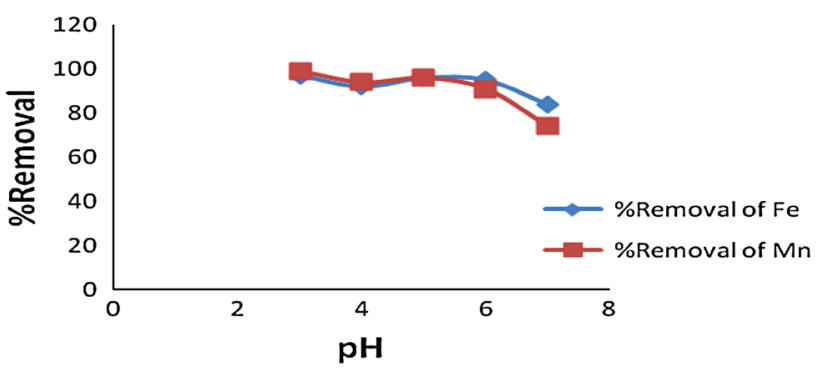

Fig. 5 Effect of $\mathrm{pH}$ on the percentage removal of $\mathrm{Mn}$ (II) and $\mathrm{Fe}(\mathrm{II})$ on Ash-RH $[m=0.1 \mathrm{~g}, V=20 \mathrm{ml}, \mathrm{pH}$ (3-7), temperature from $30{ }^{\circ} \mathrm{C}$, concentration $10 \mathrm{mg} / \mathrm{l}$, time $120 \mathrm{~min}$ ]

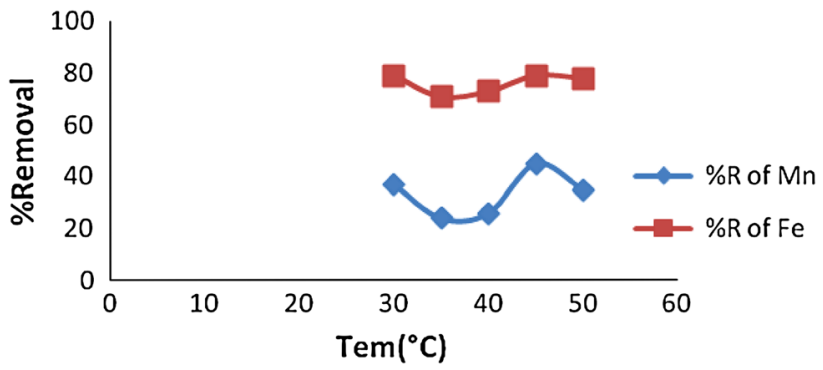

Fig. 6 Effect of temperature on the percentage removal of $\mathrm{Mn}$ (II) and $\mathrm{Fe}(\mathrm{II})$ on Ash-RH $(m=0.1 \mathrm{~g}, V=20 \mathrm{ml}, \mathrm{pH} \mathrm{5}$, temperature from 30 to $50{ }^{\circ} \mathrm{C}$, concentration $10 \mathrm{mg} / \mathrm{l}$, time $120 \mathrm{~min}$ )

$\mathrm{Mn}$ and $50 \mathrm{~min}$ for Fe. Subsequent experiment at concentrations 10, 20 and $50 \mathrm{ppm}$ was carried out at $120 \mathrm{~min}$ (Figs. 4, 5, 6).

\section{Effect of adsorbent dose}

The percent removal of both metals $\mathrm{Mn}$ (II) and $\mathrm{Fe}(\mathrm{II})$ increased with increase in Ash-RH dosage and attained a plateau (i.e. reached maximum amount) at $0.1 \mathrm{~g}$ for $\mathrm{Fe}$ and $0.5 \mathrm{~g}$ for Mn. The observed increase in the percent removal 
of the metals with increase in dose of the adsorbent (AshRH particles) can be attributed to the increase in the surface area which leads to an increase in number of active sites for adsorption (Mckay and Ho 1999; Lakshminarayanan et al. 1994). This may also be due to an increase in effective surface area resulting from the conglomeration of the adsorbent especially at higher dosage of the adsorbent (Annadurai et al. 1997; Danis et al. 1999).

\section{Effect of $\mathrm{pH}$}

The percentage removal was practically the same for the metal ions considered, as it varied between 92 and $97 \%$ for $\mathrm{Fe}$, and between 91 and $99 \%$ for $\mathrm{Mn}$ at $\mathrm{pH} 3-6$. The percentage removal, however, reduced to $84 \%$ for $\mathrm{Fe}$ and $74 \%$ for $\mathrm{Mn}$ when the $\mathrm{pH}$ was adjusted to 7 . The effect of $\mathrm{pH}$ can be explained considering the surface charge on the adsorbent material. At low $\mathrm{pH}$, due to high positive charge density and due to protons on the surface sites, during the uptake of metal ions electrostatic repulsion will be high, resulting in lower removal efficiency. Electrostatic repulsion decreases with increasing $\mathrm{pH}$ due to reduction of positive charge density on the sorption sites; thus an enhancement of metal adsorption is noted. Effect of $\mathrm{pH}$ on adsorption also has been reported by several earlier workers (Dubinin and Radushkevich 1947). At higher $\mathrm{pH}$ values $\mathrm{OH}^{-}$ions compete with the metal ions with the active sites on the surface of the adsorbents.

\section{Effect of temperature}

The equilibrium uptake of $\mathrm{Mn}(\mathrm{II})$ and $\mathrm{Fe}(\mathrm{II})$ by $0.1 \mathrm{~g}$ of Ash-RH was slightly affected by temperature. The slight variation in equilibrium uptake was more pronounced in the case of manganese than iron. It was observed that the percentage removal was practically irregular with temperature. The decrease in adsorption with the rise of temperature may be due to the formation of the adsorbateadsorbent complex which becomes unstable resulting in the escape from solid phase to the bulk solution. It is also likely that the instability of the complex may be accompanied by damage to the adsorption sites of the adsorbent thereby decreasing the metal ions uptake at higher temperature (Bhattacharyya and Gupta Sen 2006). The instability of the complex might also account for this downward and upward increase in the metal ions uptake.

Adsorption behavior of metals in binary solution

The respective concentrations of $\mathrm{Mn}$ (II) and $\mathrm{Fe}$ (II) in the experimental binary solutions used in this study are shown in Table 3.
Table 3 The respective concentrations of $\mathrm{Mn}$ (II) and Fe(II) in the experimental binary solutions

\begin{tabular}{lcc}
\hline S/no & Mn (ppm) & Fe (ppm) \\
\hline 1 & 0 & 20 \\
2 & 5 & 15 \\
3 & 10 & 10 \\
4 & 15 & 5 \\
5 & 20 & 0 \\
\hline
\end{tabular}

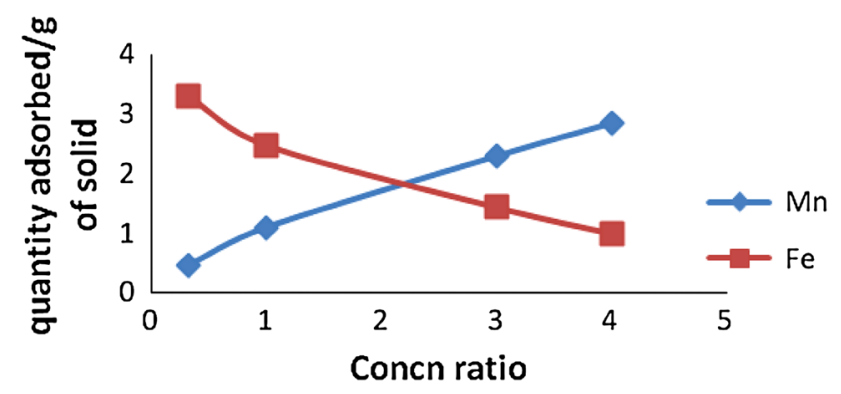

Fig. 7 Plot of adsorption behavior of $\mathrm{Mn}$ and $\mathrm{Fe}$ ions in a binary solution $\left(m=0.1 \mathrm{~g}, V=20 \mathrm{ml}\right.$, temp. $30{ }^{\circ} \mathrm{C}, \mathrm{pH} 5$, contact time $120 \mathrm{~min})$

Table 4 Thermodynamic parameters for manganese (II) and iron (II)

\begin{tabular}{llll}
\hline Metals & $\Delta G^{\mathrm{o}}(\mathrm{kJ} / \mathrm{mol})$ & $\Delta H^{\mathrm{o}}(\mathrm{kJ} / \mathrm{mol})$ & $\Delta S^{\mathrm{o}}(\mathrm{J} / \mathrm{mol} / \mathrm{K})$ \\
\hline $\mathrm{Mn}$ & -20285.76 & -10492.77 & 32.11 \\
$\mathrm{Fe}$ & -107824.62 & -57499.628 & 165.28 \\
\hline
\end{tabular}

Binary adsorption studies are important for assessing the degree of interference posed by common metal ions in adsorptive treatment of wastewaters and aqueous solutions (El-Said et al. 2010). Adsorbents generally exhibit three possible types of behavior and these are synergistic (the effect of the mixture is greater than that of the single components in the mixture), antagonism (the effect of the mixture is less than that of each of the components in the mixture) and non-interaction (the mixture has no effect on the adsorption of each of the adsorbates in the mixture) (Xiao and Thomas 2004).

The overriding effect of the binary mixture of $\mathrm{Mn}$ (II) and $\mathrm{Fe}$ (II) seems to be antagonistic in this case (Fig. 7). This is because the experimental equilibrium effect of the mixture is less than that of each of the components in the mixture. Similar results have been obtained by some authors.

Thermodynamics evaluation of adsorption process

The data obtained for the thermodynamic parameters for manganese and iron are presented in Table 4 in Fig. 8a, b. 
Fig. 8 a A plot of In $K_{\mathrm{d}}$ against $1 / T\left(\mathrm{~K}^{-1}\right)$ for $\mathrm{Mn}(\mathrm{II}) 10 \mathrm{ppm}$. b A plot of In $K_{\mathrm{d}}$ against $1 /$ $T\left(\mathrm{~K}^{-1}\right)$ for $\mathrm{Fe}(\mathrm{II}) 10 \mathrm{ppm}$

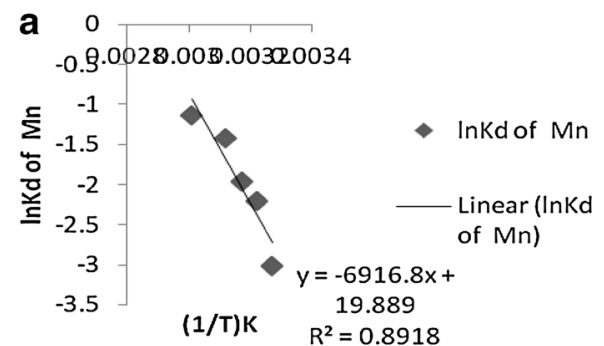

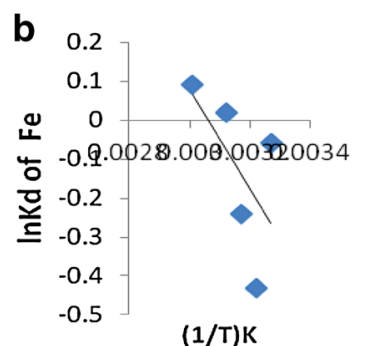

$y=-1262.3 x+$

3.8623

$R^{2}=0.3575$

- InKd of $\mathrm{Fe}$

Linear (InKd of $\mathrm{Fe}$ )

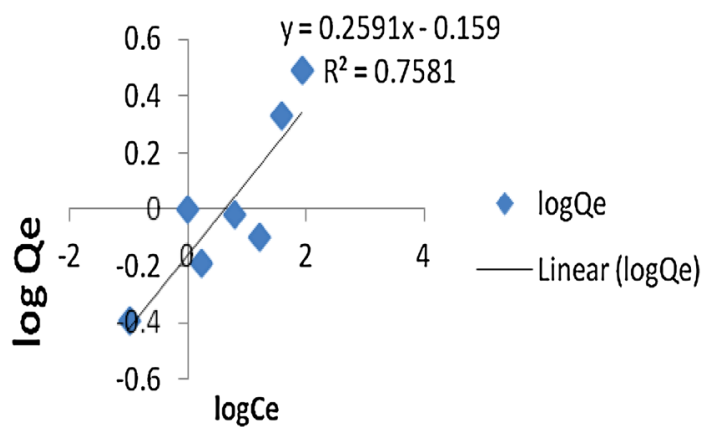

Fig. 9 Freundlich isotherm curve for manganese using Ash-RH at $\mathrm{pH}$ 5, temp. $30^{\circ} \mathrm{C}$, adsorbent dose $0.1 \mathrm{~g}$

The free energy change values obtained for the adsorption of $\mathrm{Mn}$ (II) and $\mathrm{Fe}(\mathrm{II})$ at $305 \mathrm{~K}$, initial metal concentration of $10 \mathrm{ppm}$ and $\mathrm{pH} 5$ were $-20,285.76$ and $-57,499.62 \mathrm{~kJ} \mathrm{~mol}^{-1}$, respectively. This is confirmed by thermodynamic parameters such as free energy $\left(\Delta G^{0}\right.$, $\left.\mathrm{k} \mathrm{cal} \mathrm{mol}{ }^{-1}\right)$, enthalpy $\left(\Delta H^{\mathrm{o}}, \mathrm{k} \mathrm{cal} \mathrm{mol}^{-1}\right)$ and entropy $\left(\Delta S^{\mathrm{o}}\right.$, cal mol $\left.{ }^{-1} \mathrm{k}^{-1}\right)$ changes during the process. These parameters were calculated at $305,310,315,320$ and $325 \mathrm{~K}$ temperatures (Singh et al. 1988). As the temperature increases, the values of $\Delta \mathrm{G}$ become more negative for each metal (Malakootian et al. 2008). The negative and small values of free energy change $\left(\Delta G^{0}\right)$ were an indication of the spontaneous nature of the adsorption process. The negative values of standard enthalpy change $\left(\Delta H^{0}\right)$ for the intervals of temperatures were indicative of the exothermic nature of the adsorption process. Thermodynamic constants of adsorption obtained for $\mathrm{Mn}$ (II) and $\mathrm{Fe}(\mathrm{II})$ are summarized in Table 4.

\section{Adsorption isotherms}

Adsorption data for adsorbate concentration

\section{Adsorption isotherms}

The results of the adsorption experiments in this work were described by Freundlich, Langmuir and Temkin isotherms. Batch adsorption isotherms were carried out on sorption of manganese and iron using Ash-RH at room temperature.

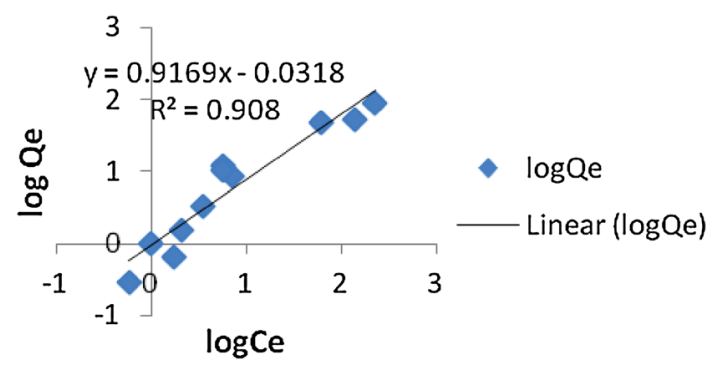

Fig. 10 Freundlich isotherm curve for manganese using Ash-RH at $\mathrm{pH} 5$, temp. $30{ }^{\circ} \mathrm{C}$, adsorbent dose $0.1 \mathrm{~g}$

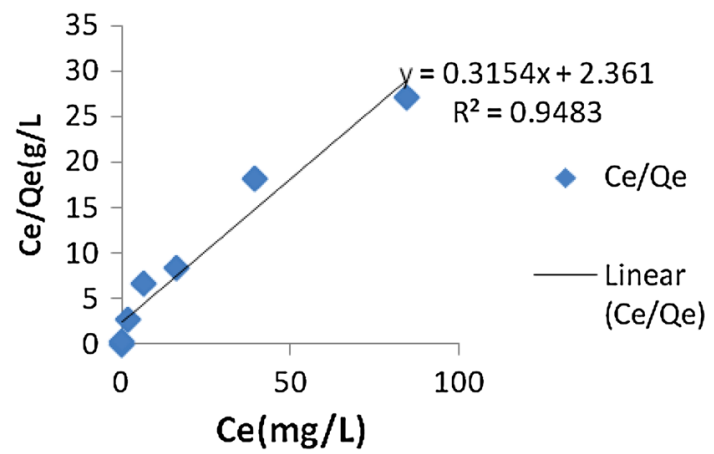

Fig. 11 Langmuir plot for sorption of $\mathrm{Mn}$ (II) ions on Ash-RH at $\mathrm{pH}$ 5, temp. $30^{\circ} \mathrm{C}$, adsorbent dose $0.1 \mathrm{~g}$

The adsorption isotherms data are illustrated in Figs. 9, 10, $11,12,13$ and 14.

The result of Freundlich isotherm best fitted adsorption of $\mathrm{Fe}$ (II) on Ash-RH with correlation coefficient $R^{2} 0.908$ and moderately fitted the adsorption for $\mathrm{Mn}$ (II) with correlation coefficient $R^{2} 0.758$. The $1 / n$ and $K_{\mathrm{f}}$ are obtained from the slope and intercept of the plot of $\ln \left(C_{\mathrm{e}}\right)$ versus $\ln$ $\left(q_{\mathrm{e}}\right)$, the values of $n$ and $K_{\mathrm{f}}$ are given in Table 5. The value of $1 / n<1$, for both metal ions implied favorable adsorption. The magnitude of $K_{\mathrm{f}}$ is a measure of the adsorbate on the adsorbent (Jalali et al. 2002; Igwe and Abia 2007). In this study, the sorption intensity on $\mathrm{Mn}$ (II) is higher than that of $\mathrm{Fe}(\mathrm{II})$.

The plots of $C_{\mathrm{e}}$ versus $C_{\mathrm{e}} / q_{\mathrm{e}}$ for $\mathrm{Mn}(\mathrm{II})$ and $\mathrm{Fe}(\mathrm{II})$ are shown in Figs. 11, 12, the linear isotherm parameters $q_{\mathrm{m}}$, $b$ and the correlation coefficient are also given in the Table 6. Maximum sorption capacity, $q_{\mathrm{m}}$ of $\mathrm{Fe}(\mathrm{II})$ is $66.66 \mathrm{mg} / \mathrm{g}$ which is greater than that of $\mathrm{Mn}$ (II) of 


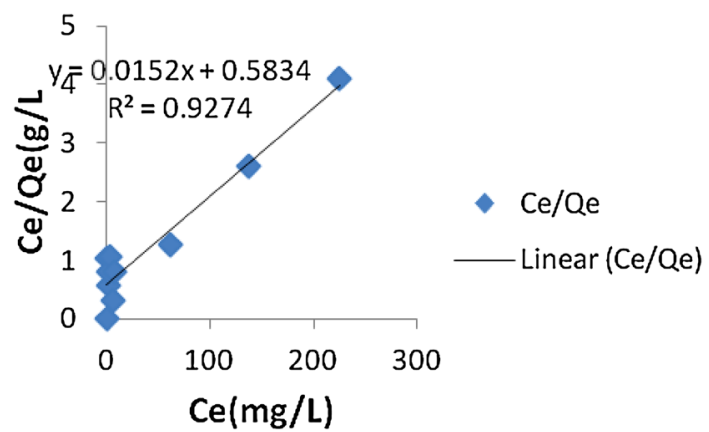

Fig. 12 Langmuir plot for sorption of $\mathrm{Mn}(\mathrm{II})$ ions on Ash- $\mathrm{RH}$ at $\mathrm{pH}$ 5 , temp. $30^{\circ} \mathrm{C}$, adsorbent dose $0.1 \mathrm{~g}$

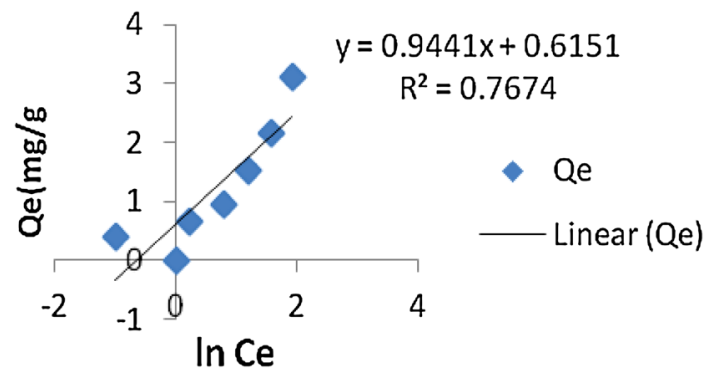

Fig. 13 Temkin plot for sorption of $\mathrm{Mn}(\mathrm{II})$ ions on Ash-RH at $\mathrm{pH}$ 5, temp. $30{ }^{\circ} \mathrm{C}$, adsorbent dose $0.1 \mathrm{~g}$

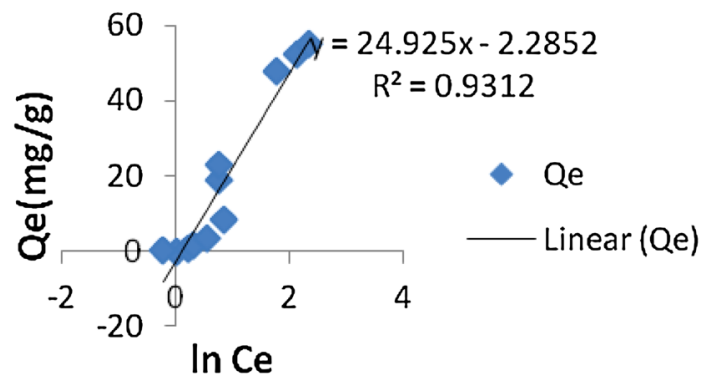

Fig. 14 Temkin plot for sorption of Fe(II) ions on Ash-RH at $\mathrm{pH}$ 5, temp. $30{ }^{\circ} \mathrm{C}$, adsorbent dose $0.1 \mathrm{~g}$

Table 5 Freundlich constants

\begin{tabular}{llllll}
\hline Metal ions & $1 / n$ & $\log K_{\mathrm{f}}$ & $R^{2}$ & $n$ & $K$ \\
\hline Mn(II) & 0.259 & 0.159 & 0.758 & 3.861 & 1.4421 \\
$\mathrm{Fe}(\mathrm{II})$ & 0.916 & 0.031 & 0.908 & 1.091 & 1.0739 \\
\hline
\end{tabular}

$3.17 \mathrm{mg} / \mathrm{g}$, this shows that the Ash-RH has greater ability to adsorb Fe(II) than Mn(II). Better fitting of the experimental data to Langmuir isotherm with regression coefficient of 0.948 and 0.927 for $\mathrm{Mn}(\mathrm{II})$ and $\mathrm{Fe}(\mathrm{II})$ indicate monolayer adsorption of $\mathrm{Mn}$ (II) and $\mathrm{Fe}(\mathrm{II})$ which may be due to homogeneous distribution of active sites onto adsorbent surface.

The plots of $\ln \left(C_{\mathrm{e}}\right)$ versus $q_{\mathrm{e}}$ for $\mathrm{Mn}$ (II) and $\mathrm{Fe}(\mathrm{II})$ are shown in Figs. 13, 14 and the linear isotherm parameters
Table 6 Langmuir constants

\begin{tabular}{lllllrl}
\hline Metal ions & $1 / q_{\mathrm{m}}$ & $1 / b q_{\mathrm{m}}$ & $R^{2}$ & $b$ & $q_{\mathrm{m}}$ & $R_{\mathrm{L}}$ \\
\hline $\mathrm{Mn}(\mathrm{II})$ & 0.315 & 2.361 & 0.948 & 0.1336 & 3.17 & 0.4281 \\
$\mathrm{Fe}(\mathrm{II})$ & 0.015 & 0.583 & 0.927 & 0.0257 & 66.66 & 0.7956 \\
\hline
\end{tabular}

Table 7 Temkin constants

\begin{tabular}{lclllc}
\hline $\begin{array}{l}\text { Metal } \\
\text { ions }\end{array}$ & Slope $=R T / B$ & $\begin{array}{l}\text { Intercept }=R T / \\
B(\operatorname{In} A)\end{array}$ & $R^{2}$ & $B$ & $A$ \\
\hline $\mathrm{Mn}(\mathrm{II})$ & 0.944 & 0.615 & 0.767 & 2686.2 & 4.64 \\
$\mathrm{Fe}(\mathrm{II})$ & 24.92 & 2.285 & 0.931 & 101.76 & 54.5 \\
\hline
\end{tabular}

$B, K_{\mathrm{T}}$ and the correlation coefficient are given in Table 7 . Constant $B$ is related to heat of sorption, for $\mathrm{Mn}$ (II) it is 2,686.2 and $101.76 \mathrm{~kJ} / \mathrm{mol}$ for $\mathrm{Fe}(\mathrm{II})$. Therefore, $K_{\mathrm{T}}$ which is the equilibrium binding constant for Fe(II) is greater than $\mathrm{Mn}(\mathrm{II})$, indicating a lower biomass metal ion potential for Mn(II) (Table 8).

The values of the linear regression coefficient $\left(R^{2}\right)$ indicate that Langmuir, Freundlich and Temkin isotherms fit the equilibrium experimental data for $\mathrm{Fe}(\mathrm{II})$ while Langmuir best fit for Mn(II).

The direct comparison of adsorbent capacity of these rice husk ash with other sorbents reported in the literature is different due to varying experimental conditions employed in those studies. However, the solids in this study possess reasonable adsorption capacity in comparison with other adsorbents.

\section{Adsorption kinetics}

A good understanding of batch adsorption kinetics is needed for the design and operation of adsorption for Mn(II) and $\mathrm{Fe}$ (II) treatment. The nature of the $\mathrm{Mn}$ (II) and $\mathrm{Fe}$ (II) adsorption kinetic process depends on the physical or chemical characteristics of the adsorbent and also on the operating conditions. The kinetic data of $\mathrm{Mn}$ (II) and $\mathrm{Fe}(\mathrm{II})$ interactions with rice husk ash were, therefore, tested with different models such as pseudo-first order, pseudo-second order, intra-particle diffusion and liquid film diffusion model.

Only the pseudo-second order equation fitted best the kinetic data. The adsorption kinetic data for the various models are presented Figs. 15, 16.

Linear plot of $t$ versus $t / q_{\mathrm{t}}$ (Figs. 15, 16) was used to determine the rate constants and correlation coefficients. For both $\mathrm{Mn}(\mathrm{II})$ and $\mathrm{Fe}$ (II) ions adsorption, the values of correlation coefficients of the data, were found to be very high $\left(R^{2}>0.99\right)$. These values are shown in Table 9 . The rate constant $K$ obtained from slope of plot of $t$ versus $t / q_{\mathrm{t}}$, for $\mathrm{Mn}(\mathrm{II})$ is $0.292 \mathrm{mg} / \mathrm{g} \mathrm{min}$, as much greater than that of $\mathrm{Fe}$ (II) 
Table 8 Comparison of results obtained in this study for the removal of $\mathrm{Mn}$ (II) with those of other adsorbents

\begin{tabular}{|c|c|c|c|c|c|c|}
\hline \multirow[t]{2}{*}{ Adsorbents } & \multirow[t]{2}{*}{$\mathrm{pH}$} & \multicolumn{2}{|l|}{ Langmuir } & \multicolumn{2}{|l|}{ Freundlich } & \multirow[t]{2}{*}{ References } \\
\hline & & $q(\mathrm{mg} / \mathrm{g})$ & $b(1 / \mathrm{mg})$ & $K_{\mathrm{f}}(\mathrm{mg} / \mathrm{g})$ & $n(1 / \mathrm{mg})$ & \\
\hline Clay & 4 & 3.80 & 0.0589 & 12.91 & 1.07 & (Eba et al. 2010) \\
\hline Clay & 4 & 7.79 & 0.0415 & 12.32 & 1.27 & (Eba et al. 2010) \\
\hline Pristine Tamarindus fruit nut shell & 4 & 122 & 0.0164 & 2.7 & 1.2 & (Suguna et al. 2010) \\
\hline Acid treated Tamarindus fruit nut shell & 4 & 182 & 0.0218 & 4.6 & 1.2 & (Suguna et al. 2010) \\
\hline Activated carbon & & 27.78 & 0.2628 & 8.3645 & 2.72 & (Chowdhury et al. 2011) \\
\hline Activated carbon & 7 & 0.2838 & 0.1067 & 0.3423 & 4.995 & (Eba et al. 2010) \\
\hline Activated carbon & 7 & 0.4433 & 0.3087 & 0.1110 & 3.276 & (Emmanuel and Veerabhadra 2009) \\
\hline Rice husk ash & 5 & 0.1336 & 3.17 & 3.861 & 1.4421 & This study \\
\hline
\end{tabular}

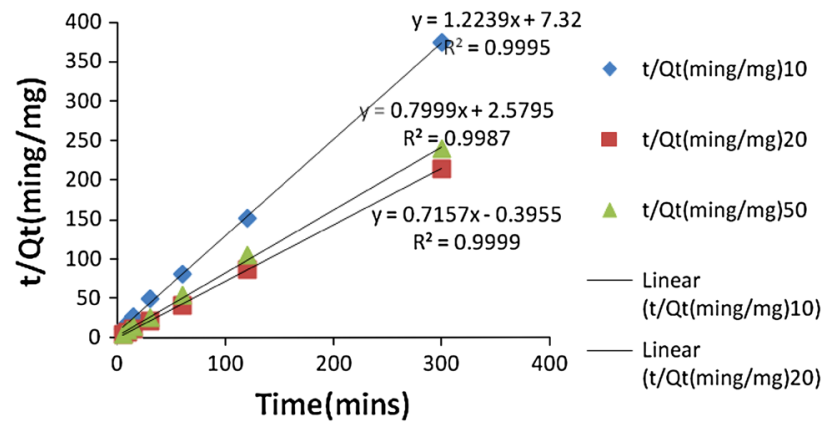

Fig. 15 Pseudo-second order kinetics for sorption of Ash-RH on Mn at $\mathrm{pH} 5$, temp. $30{ }^{\circ} \mathrm{C}$, adsorbent dose $0.1 \mathrm{~g}$

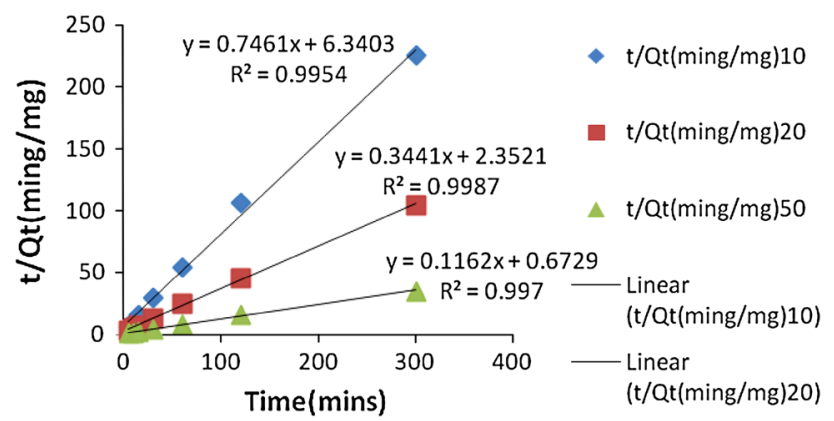

Fig. 16 Pseudo-second order kinetics for sorption of Ash-RH on $\mathrm{Fe}$ at $\mathrm{pH} 5$, temp. $30{ }^{\circ} \mathrm{C}$, adsorbent dose $0.1 \mathrm{~g}$

which is $0.033 \mathrm{mg} / \mathrm{g}$ min at the same concentration of $10 \mathrm{ppm}$. This observation showed that $\mathrm{Mn}$ (II) ions adsorption takes place at higher rate than that of Fe(II) ions. The calculated $q_{\mathrm{e}}$ value from the pseudo-second order model is in good agreement with the experimental $q_{\mathrm{e}}$ value. This suggests that the sorption followed the pseudo-second order model (Muraleedharan and Venkobachar 1990; Park et al. 2006).

Characterization of Ash-RH using IR spectroscopy

The FTIR technique is an important tool to identify the characteristic functional groups (Fig. 17). The important peaks
Table 9 Pseudo second order constants extracted from Figs. 15, 16

\begin{tabular}{lllllll}
\hline $\begin{array}{l}\text { Metal } \\
\text { ions }\end{array}$ & $\begin{array}{l}\text { Concn } \\
(\mathrm{mg} / \mathrm{l})\end{array}$ & Slope $=1 / q_{\mathrm{e}}$ & Intercept & $R^{2}$ & $\begin{array}{l}K_{2}(\mathrm{~g} / \mathrm{mg} / \\
\mathrm{min})\end{array}$ & $\begin{array}{l}q_{\mathrm{e}} \\
(\mathrm{cal})\end{array}$ \\
\hline $\mathrm{Mn}(\mathrm{II})$ & 10 & 1.223 & 7.32 & 0.999 & 0.292 & 0.818 \\
& 20 & 0.799 & 2.579 & 0.998 & 0.965 & 1.251 \\
& 50 & 0.715 & -0.395 & 0.999 & 0.075 & 1.40 \\
$\mathrm{Fe}(\mathrm{II})$ & 10 & 0.746 & 6.340 & 0.995 & 0.033 & 1.340 \\
& 20 & 0.344 & 2.352 & 0.998 & 0.026 & 2.91 \\
& 50 & 0.116 & 0.672 & 0.997 & $6.63 \times 10^{-3}$ & 8.621
\end{tabular}

extracted from the infrared (IR) spectra of the Ash-RH are summarized in Table 10. The different functional groups are of vital importance in understanding the adsorption process of the adsorbent. The infrared (IR) spectra of the samples had a broad band in the region of $3,433.41-3,446.91 \mathrm{~cm}^{-1}$ due to the surface $\mathrm{O}-\mathrm{H}$ vibration. This band is due to the silanol, $\mathrm{SiO}-\mathrm{H}$ groups and the $\mathrm{HO}-\mathrm{H}$ vibration of the adsorbed water molecules bound to the silica surface (Kamath and Proctor 1998). This surface silanol groups are responsible for physically adsorbing water molecules and holding them in place by hydrogen bonding. The peak around 1,641.48-1,737.92 $\mathrm{cm}^{-1}$ corresponds to $\mathrm{C}=\mathrm{O}$ stretching of aromatic groups that may be attributed to the hemicelluloses and lignin aromatic group. The $\mathrm{C}=\mathrm{C}$ stretching vibrations between 1,514.17 and $1,656.91 \mathrm{~cm}^{-1}$ are indicative of alkenes and aromatic functional groups. The peaks around $1,471.74-1,462.09 \mathrm{~cm}^{-1}$ indicate the presence of $\mathrm{CH}_{2}$ and $\mathrm{CH}_{3}$. The peaks in the $1,163.11-1,315.5 \mathrm{~cm}^{-1}$ correspond to vibration of $\mathrm{CO}$ group in lactones. The peaks around $469.32-800 \mathrm{~cm}^{-1}$ indicate the presence of $-\mathrm{OCH}_{3}$. All linkages present on the biomass surface are responsible for metal uptake process (Wong et al. 2000; Nadeem et al. 2006; Skoog et al. 2007).

Turbidity measurement

The result of turbidity measurement depicting the rate of sedimentation of rice husk particles as a function of time 
Fig. 17 IR spectra of the adsorbent Ash-RH A plot of turbidity of Ash-RH particles against time

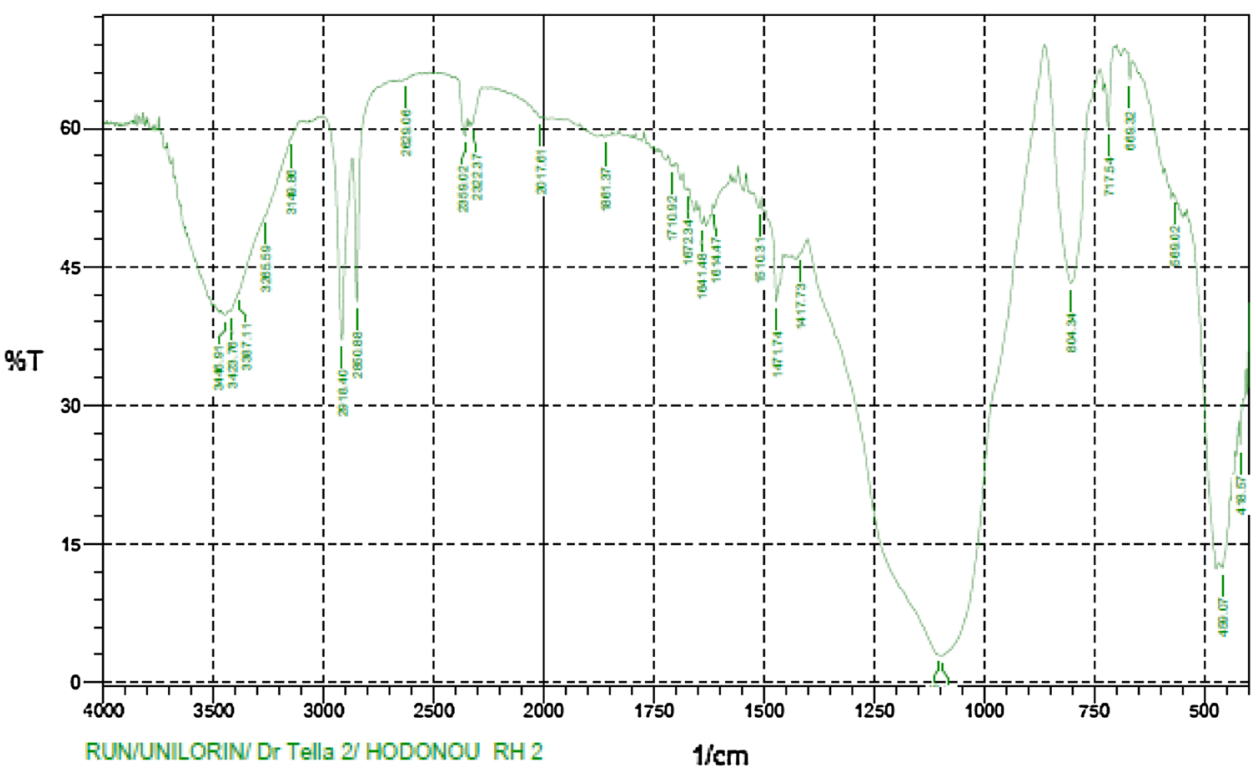

Table 10 Functional groups presents in Ash-RH

\begin{tabular}{ll}
\hline Ash-RH & Assignment \\
\hline $3,446.91$ & $-\mathrm{OH}$ and $\mathrm{Si}-\mathrm{OH}$ \\
$2,918.4$ & $\mathrm{C}-\mathrm{H}$ stretching of alkanes \\
$1,641.48$ & $\mathrm{C}=\mathrm{O}$ stretching of aromatic groups \\
$1,510.31$ & $\mathrm{C}=\mathrm{C}$ stretching of alkenes and aromatic \\
$1,471.74$ & $\mathrm{CH}_{2}$ and $\mathrm{CH}_{3}$ \\
$1,105.25$ & $\mathrm{CO}$ group in lactones \\
459.07 & $-\mathrm{OCH}_{3}$ \\
\hline
\end{tabular}

and $\mathrm{pH}$ are illustrated in Fig. 18. It is evident that turbidity decreases exponentially with time. It can be seen that the NTU decreases as the time increases. A practically clear supernatant was obtained within $15 \mathrm{~min}$. So the suspension will, therefore, require continuous agitation of suspension during the adsorption process for the attachment of adsorptive metal ions on the adsorbents.

\section{Desorption results}

Desorption studies help to elucidate the nature of adsorption and recycling of the spent adsorbent. For desorption studies of the spent adsorbent, various concentrations of $\mathrm{HCl}$ solutions from 0.05 to $0.1 \mathrm{M}$ were used. Maximum percents desorption obtained for men (II) and Fe(II) were 67 and $86 \%$, respectively, within $2 \mathrm{~h}$ for $0.1 \mathrm{M}$ concentration of $\mathrm{HCl}$. The results are illustrated in Fig. 19 for Ash-RH. It is important to note that at low concentration, the desorption solution was able to quantitatively remove the metal ions from the adsorbent, thereby reducing the expenses and waste generation.

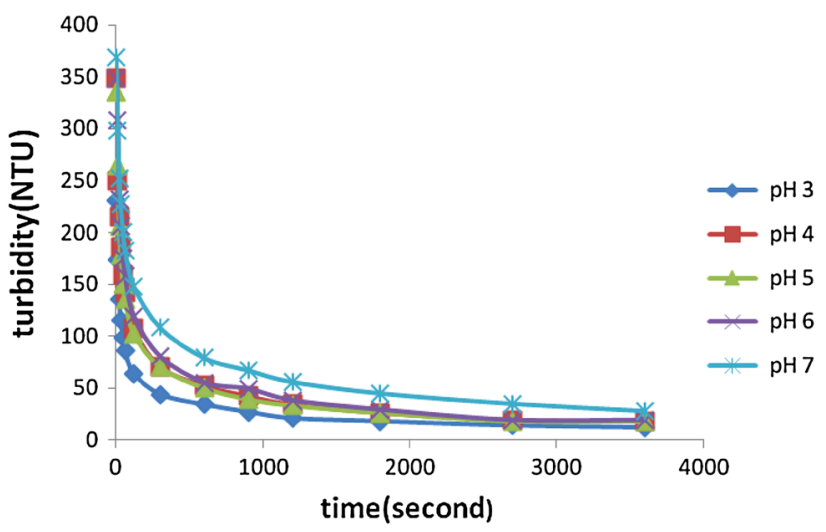

Fig. 18 Rate of sedimentation of Ash-RH with respect to time and $\mathrm{pH}$

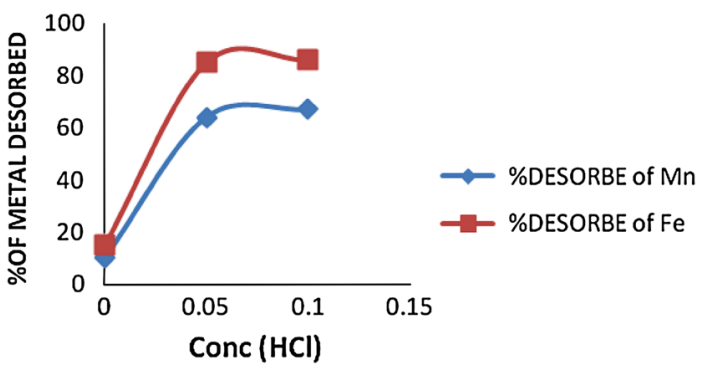

Fig. 19 A plot of percentage desorbed against molar concentration of $\mathrm{HCl}$ for $\mathrm{Mn}$ and $\mathrm{Fe}$

Desorption index

The desorption index of Ash-RH with respect to Mn(II) and $\mathrm{Fe}(\mathrm{II})$ have been calculated and the values are summarized in Table 11. 
Table 11 Desorption indices of $\mathrm{Mn}(\mathrm{II})$ and $\mathrm{Fe}(\mathrm{II})$

\begin{tabular}{lll}
$\begin{array}{l}\mathrm{HCl} \text { concentration } \\
(\mathrm{M})\end{array}$ & $\begin{array}{l}\text { Desorption index of } \\
\mathrm{Mn}\end{array}$ & $\begin{array}{l}\text { Desorbed index of } \\
\mathrm{Fe}\end{array}$ \\
\hline 0.05 & 1.163 & 0.834 \\
0.1 & 1.165 & 0.841 \\
0.2 & 1.158 & 0.846 \\
\hline
\end{tabular}

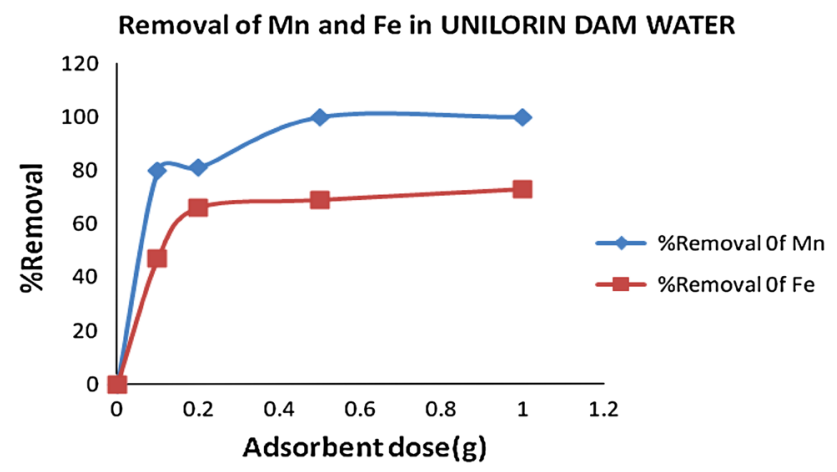

Fig. 20 A plot of percentage removal of $\mathrm{Mn}$ and Fe from Unilorin dam raw water against adsorbent dose $\mathrm{pH}=3$, temp $=30{ }^{\circ} \mathrm{C}$, initial conc $\mathrm{Mn}(\mathrm{II})=3.808 \mathrm{ppm}$ and $\mathrm{Fe}^{2+}=6.28 \mathrm{ppm}$

The values of the desorption index (DI) were calculated for various concentrations of $\mathrm{HCl}$ from 0.05 to $0.2 \mathrm{M}$ to evaluate the degree of reversibility of $\mathrm{Mn}$ (II)-Ash-RH and $\mathrm{Fe}(\mathrm{II})-\mathrm{Ash}-\mathrm{RH}$ sorption process. A sorption process is considered to be completely reversible when DI equals 1 . The degree of irreversibility of a sorption reaction increases as DI value deviates from 1 (Adekola et al. 2012). In this study, the DI value for Mn(II)-Ash-RH ranged from 1.158 to 1.163 , while that of $\mathrm{Fe}(\mathrm{II})-\mathrm{Ash}-\mathrm{RH}$ ranged from 0.834 to 0.846 . The DI values are close to 1 which implies that the sorption process is practically reversible within the concentration range investigated.

\section{Result of batch optimization conditions for the removal of $\mathrm{Mn}$ and $\mathrm{Fe}$ from untreated dam water}

The results are illustrated in Fig. 20. It is interesting to note that $100 \%$ of $\mathrm{Mn}(\mathrm{II})$ and nearly $70 \%$ of $\mathrm{Fe}(\mathrm{II})$ were removed from the raw water after a contact time of $2 \mathrm{~h}$ and with adsorbent dose of $0.5 \mathrm{~g}$.

\section{Conclusion}

The Ash-RH (rice husk ash) was found to be an effective biosorbent for the removal of $\mathrm{Mn}$ (II) and $\mathrm{Fe}$ (II) from an aqueous solution. The study showed that the initial concentration, contact time, the adsorbents dose, temperature and $\mathrm{pH}$ of the solution influenced the adsorption process. Thermodynamic studies showed that the adsorption process was feasible and spontaneous and exothermic in nature. A good fit of the adsorption data into the Langmuir isotherm confirmed monolayer adsorption for both metals $\mathrm{Mn}$ and Fe. The prepared rice husk effectively removed manganese and iron from the raw water of the University of Ilorin dam.

Open Access This article is distributed under the terms of the Creative Commons Attribution License which permits any use, distribution, and reproduction in any medium, provided the original author(s) and the source are credited.

\section{References}

Abdullah AH, Kassim A, Zainal Z, Zobir Hussien M, Faujan Ahmad D, Wool O (2001) Preparation \& characterization of activated carbon from gelam wool bark. Malays J Anal Sci 7(1):65-68

Adekola FA, Abdulssalam N, Adegoke HI, Adesola AM, Adekeye JID (2012) Removal of $\mathrm{Pb}$ (II) from aqueous solution by Natural and synthetic Calcites. Bull Chem Soc Ethiopia 26(2):195-210

Annadurai G, Chellapandian M, Krishnan MRV (1997) Adsorption of basic dye from aqueous solution by chitosan: equilibrium studies. Indian J Env Prot 17(2):95-98

Bhattacharyya KG, Gupta Sen S (2006) Pb(II) uptake by kaolinite and montmorillonite in aqueous medium influence of acid activation of the clays. Coll Surf A Physiochem Eng Aspects 277:191-200

Chowdhury ZZ, Zain SM, Khan RA, Ahmad AA, Islam MS, AramiNiya A (2011) Application of central composite design for preparation of Kenaf fiber based activated carbon for adsorption of Manganese (II) ion. Int J Phys Sci 6(31):7191-7202

Danis U, Gurses A, Caupolat N (1999) Removal of some azo dyes from wastewater using PAC as adsorbent. Fres Env Bull $8: 358-365$

Dubinin MM, Radushkevich LV (1947) Equation of the Characteristic curve of activated charcoal. Chemisches Zentralblatt $1: 875-890$

Eba F, Gueu S, Mvongbote EA, Ondo JA, Yao BK, Ndong Nlo J, Kouya Bibouta R (2010) Evaluation of the adsorption capacity of the natural clay from BiKougou (Gabon) to remove $\mathrm{Mn}$ (II) froms aqueous solution. Int J Eng Sci Technol 2(10):5001-5016

El-Said AG, Badawy NA, Garamon SE (2010) Adsorption of Cadmium (II) and Mercury (II) onto natural adsorbent rice husk ash (RHA) from aqueous solutions: study in single and binary system. J Am Sci 6(12):400-409

Emmanuel KA, Veerabhadra Rao A (2009) Comparative study on adsorption of $\mathrm{Mn}$ (II) from aqueous solutions on various activated carbons. E-J Chem 6(3):693-704

Hall KR, Eggleton LC, Acrivos A, Vermeulan TH (1966) Pore- and solid-diffusion kinetics in fixed bed adsorption under constantpattern conditions. Ind Eng Chem Fundam 5(2):212-223

Ho YS, McKay G (2002) Application of kinetic models to the sorption of $\mathrm{Cu}$ (II) onto Peat. Adsorpt Sci Technol 20(8): $797-815$

Ho YS, Wase DAJ, Forster CF (1996) Kinetics studies of competitive heavy metal adsorption by Sphagnum moss peat. Environ Technol 17:71-77

Hutson ND, Yang RT (1997) Theoretical basis for the DubininRadushkevich (D-R) adsorption isotherm equation. Adsorption. 3:189-195

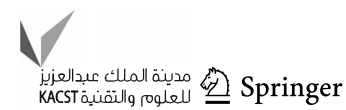


Igwe JC, Abia AA (2007) Equilibrium sorption isotherm studies of $\mathrm{Cd}$ (II), $\mathrm{Pb}$ (II) and $\mathrm{Zn}$ (II) ion detoxification from waste water using unmodified and EDTA-modified Maize husk. Electron J Biotechnol 10(4):102-125

Jahn SAA (1988) Using Moringa Oleifera seeds as coagulant developing countries. J Am Water Works Assoc 6:43-50

Jalali R, Ghafourian H, Asef Y, Davarpanah SJ, Sepehr S (2002) Removal and recovery of lead using non-living biomass of marine algae. J Hazard Mater 92:253-262

Kalavathy MH, Miranda LR (2010) Moringa Oleifera—a solid phase extractant for the removal of copper and zinc from aqueous solutions. Chem Eng J 158:188-199

Kamath SR, Proctor A (1998) Silica gel from rice hull ash: preparation and characterization. Cereal Chem 75:484-487

Khan AR, Tahir H, Uddin F, Hammed U (2005) Adsorption of methylene blue from aqueous solution on the surface of wool fibre and cotton fibre. J Appl Sci Environ Manag 9(2):29-35

Lakshminarayanan KC, Rao K, Krishna A (1994) Colour removal from the dyestuff industry effluent using activated carbon. Indian J Chem Technol 1:13-19

Laurence MH, Christopher JM (1989) Experimental organic chemistry: principles and practice (Illustrated Ed.). Wiley-Blackwell, New York, p. 292

Malakootian M, Almasi A, Hanoi H (2008) Pb and Co removal from paint industries effluent using wood ash. Int J Environ Sci Technol 5(2):217-222

Mckay G, Ho YS (1999) Pseudo-second order model for sorption process. Biochemistry 34:451-465

Mohan S, Karthikeyan J (1997) Removal of lignin and tannin colour from aqueous solution by adsorption onto activated. Environ Pollut 97:183-187

Muraleedharan TR, Venkobachar C (1990) Mechanism of biosorption of $\mathrm{Cu}$ (II) by Ganoderma lucidum. Biotechnol Bioeng $35: 320-325$
Nadeem M, Mahmood A, Shahid SA, Shah SS, Khalid AM, McKaye G (2006) Sorption of lead from aqueous solution by chemically modified carbon adsorbents. J Hazard Mater B138:604-613

Park D, Yun YS, Lim SR, Park JM (2006) Kinetic analysis and mathematical modeling of $\mathrm{Cr}(\mathrm{VI})$ removal in a different reactor parked with ecklonia biomass. J Microbiol Biotechnol 16(2): $1720-1727$

Sari A, Mendil D, Tuzen M, Soylak M (2008) Biosorption of Cd(II) and $\mathrm{Cr}$ (II) from aqueous solution by moss (Hylocomium splendens) biomass: equilibrium, kinetic and thermodynamic studies. Chem Eng J 144:1-9

Sari A, Tuzen M (2009) Kinetic and equilibrium studies of biosorption of $\mathrm{Pb}$ (II) and $\mathrm{Cd}$ (II) from aqueous by macrofungus (Amanita rubescens) biomass. J Hazard Mater 164:1004-1011

Singh DB, Prasad G, Rupainwar DC, Singh VN (1988) As (III) removal from aqueous solution by adsorption. Water Air Soil Poll 42:373-386

Spellman FR (2001) Handbook for waterworks operator certification, vol 2. Technomic Publishing Company Inc., Lancaster, pp 6-11, $81-83$

Suguna MS, Siva Kumar N, Venkata Subbaiah M, Krishnaiah A (2010) Removal of divalent manganese from aqueous solution using Tamarindus indica fruit nut shell. J Chem Pharm Res 2(1):7-20

Temkin M, Pyzhev JAV (1940) Kinetics of ammonia synthesis on promoted iron catalysts. Acta Physiochem. 12:217-222

Voudrias E, Fytianosand F, Bozani E (2002) Sorption description isotherms of dyes from aqueous solutions and waste waters with different sorbent materials, global nest. Int J 4(1):75-83

Wong JPK, Wong YS, Tam NFY (2000) Ni(II) biosorption by two choeral species, $C$. vulgaris (a commercial species) and $C$. miniata (a local isolate). Bioresour Technol 73:133-137

Xiao B, Thomas KM (2004) Competitive adsorption of aqueous metal ions on an oxidized nanoporous activated carbon. Langmuir Am Chem Soc 20:4566-4578 